Research Article

\title{
The Influence of Education Level and Occupation of Pregnant Women to the use of Maternal and Child Health (MCH) Handbook
}

\author{
Pengaruh Tingkat Pendidikan dan Pekerjaan Ibu Hamil dengan Pemanfaatan \\ Buku Kesehatan Ibu dan Anak (KIA)
}

\author{
Renny Aditya, Samuel Tobing, Miftahul Jannah \\ Department of Obstetrics and Gynecology \\ Faculty of Medicine Universitas Lambung Mangkurat \\ Ulin Hospital, Banjarmasin
}

\begin{abstract}
Objective : To investigate the relationship between education level and occupation of pregnant women with $\mathrm{MCH}$ handbook utilization at the Pekauman Public Health Center of Banjarmasin in July-August 2018.

Methods : The method that was used is analytical observational research with cross-sectional design. The number of research sample is 50 people with systematic random sampling techniques, and data were analyzed by chi-square statistical tests.

Results : The majority of respondents were 34 pregnant women (68\%) with low education level, and36 pregnant women $(72 \%)$ were unemployed. There were 36 pregnant women $(72 \%)$ with ineffective $\mathrm{MCH}$ handbook utilization. The statistical result between education level of pregnant women with $\mathrm{MCH}$ handbook utilization is $\mathrm{p}$-value $=0.005$ $(p<0.05)$ and between occupation of pregnant woman with MCHhandbook utilization is $p$-value $=0.001(p<0.05)$.

Conclusions : There a significant relationship of education leveland occupation of pregnant women with $\mathrm{MCH}$ handbook utilization at the Pekauman Public Health Center of Banjarmasin in July-August 2018.
\end{abstract}

Keywords : level ofeducation, occupation, MCH handbook.

\begin{abstract}
Abstrak
Tujuan : Untuk mengetahui hubungan tingkat pendidikan dan pekerjaan Ibu hamil dengan pemanfaatan buku KIA di Puskesmas Pekauman Banjarmasin Periode Juli-Agustus 2018.
\end{abstract}

Metode : Metode yang digunakan adalah observasional analitik dengan desain potong lintang. Besar sampel penelitian adalah 50 orang dengan teknik pengambilan systematic random sampling dan data dianalisis dengan uji statistik chi square.

Hasil : Sebagian besar responden adalah 34 ibu hamil (68\%) dengan tingkat pendidikan rendah dan 36 ibu hamil (72\%) yang tidak bekerja. Terdapat 36 ibu hamil (72\%) dengan pemanfaatan buku KIA yang tidak efektif. Hasil uji statistik antara tingkat pendidikan ibu hamil dengan penggunaan buku KIA adalah $p$ value $=0.005$ ( $p<0.05)$ dan antara pekerjaan ibu hamil dengan pemanfaatan buku KIA adalah $p$ value $=0.001(p<0.05)$

Kesimpulan : Terdapat hubungan yang bermakana tingkat pendidikan dan pekerjaan ibu hamil dengan pemanfaatan buku KIA di Puskesmas Pekauman Banjarmasin periode JuliAgustus 2018.

Kata kunci : tingkat pendidikan, pekerjaan, buku KIA.

Correspondence author: Renny Aditya; rennyaditya@gmail.com

\section{INTRODUCTION}

Maternal and Child Health ( $\mathrm{MCH}$ ) handbook is complete records and media information for pregnant women and her baby. ${ }^{1}$ The government provides the $\mathrm{MCH}$ handbook to reduce Maternal Mortality Rate (MMR) and Infant Mortality Rate (IMR). ${ }^{2}$ However, previous research found out that most of theMCH handbook utilization by pregnant women wasstill ineffective. ${ }^{3} \mathrm{MCH}$ handbook utilization as health behaviour is influenced by predisposing factors such as the level of intelligence, emotional level, information, and characteristics (age, education, occupation, and experience). ${ }^{4,5}$ Based on this, the researcher aims to find out the relationship between education level and occupation of pregnant women with $\mathrm{MCH}$ handbook utilization. Based on the results of this study, it is expected that the government and health worker can conduct counselling on target.

\section{METHODS}

The method that was used is analytical observational research with a cross-sectional 
design, using a questionnaire to pregnant women who made antenatal care visits at the Pekauman Public Health Center of Banjarmasin in JulyAugust 2018. The number of research sample is 50 people with systematic random sampling techniques according to inclusion and exclusion criteria. The data were analyzed by chi-square statistical tests and Fisher alternative test (if expected count $<5$ ). Because the data obtained one cell (25\%) with expected count 4.48 at the level of higher education and effective use and one cell (25\%) with expected count 3.92 in the working category and effective use, which is $<5$ so that alternative tests were used with Fisher's test.

Table. 1 Distribution of Respondents Based on MCH Handbook Utilization at the Pekauman Public Health Center of Banjarmasin in July-August 2018

\begin{tabular}{lcc}
\hline MCH handbook utilization & $\mathbf{n}$ & $\%$ \\
\hline Ineffective & 36 & 72 \\
Effective & 14 & 28 \\
Total & 50 & 100 \\
\hline
\end{tabular}

The statistical results for the relationship of education level and occupation of pregnant women with $\mathrm{MCH}$ handbook utilization are presented in Table 2.

Table. 2 The Relationship of the Education level of Pregnant Women with MCH Handbook Utilization at the Pekauman Public Health Center of Banjarmasin in July-August 2018

\begin{tabular}{|c|c|c|c|c|c|c|c|}
\hline \multirow[t]{3}{*}{$\begin{array}{l}\text { Education level of } \\
\text { pregnant women }\end{array}$} & \multicolumn{4}{|c|}{$\begin{array}{l}\text { MCH handbook } \\
\text { Utilization }\end{array}$} & \multirow[t]{2}{*}{ Total } & \multirow[t]{2}{*}{$P$-value } & \multirow[t]{2}{*}{ OR } \\
\hline & \multicolumn{2}{|c|}{ Ineffective } & \multicolumn{2}{|c|}{ Effective } & & & \\
\hline & $\mathbf{n}$ & $\%$ & $\mathbf{n}$ & $\%$ & $\%$ & \multirow{3}{*}{0.005} & \multirow{3}{*}{7.457} \\
\hline $\begin{array}{l}\text { Low } \\
\text { education }\end{array}$ & 29 & 85.3 & 5 & 14.7 & 100 & & \\
\hline $\begin{array}{l}\text { High } \\
\text { education }\end{array}$ & 7 & 43.8 & 9 & 56.2 & 100 & & \\
\hline
\end{tabular}

Table. 3 The Relationship of Occupation of Pregnant Women with MCH Handbook Utilization at the Pekauman Public Health Center of Banjarmasin in July-August 2018

\begin{tabular}{|c|c|c|c|c|c|c|c|}
\hline \multirow[t]{3}{*}{$\begin{array}{l}\text { Occupation of } \\
\text { pregnant women }\end{array}$} & \multicolumn{4}{|c|}{$\begin{array}{l}\text { MCH handbook } \\
\text { Utilization }\end{array}$} & \multirow[t]{2}{*}{ Total } & \multirow[t]{2}{*}{ P-value } & \multirow[t]{2}{*}{ OR } \\
\hline & \multicolumn{2}{|c|}{ Ineffective } & \multicolumn{2}{|c|}{ Effective } & & & \\
\hline & $\mathbf{n}$ & $\%$ & $\mathbf{n}$ & $\%$ & $\%$ & \multirow{3}{*}{0.001} & \multirow{3}{*}{11.160} \\
\hline Non-working & 31 & 86.1 & 5 & 13.9 & 100 & & \\
\hline Working & 5 & 35.7 & 9 & 64,3 & 100 & & \\
\hline
\end{tabular}

\section{DISCUSSION}

In this study, pregnant women with low education level have the highest number, which is $68 \%$. Someone's education level can be influenced by the motivation of individuals to pursue education (ideals), social conditions (family and community environment), family economic conditions, parent motivation, culture, and accessibility to educational facilities (distance, travel time, road facilities and transportation). ${ }^{6}$

Among respondents, most pregnant women do not work, which is $72 \%$. Occupation describes the position of a person in society and occupation also describes a person's economic ability to 
meet their needs. Occupation is also related to the level of someone's busy life. ${ }^{7}$

Most of the respondents are ineffective in using $\mathrm{MCH}$ handbook, which is $72 \%$. Green states that health behaviour is influenced by three factors, namely predisposing factors, supporting factors, and driving factors. Predisposing factors include attitudes, beliefs, knowledge, values and culture that are manifested in education, work, age, experience, culture and information. Supporting factors include the distance of health services, family economic status, and availability of facilities. The driving factors include motivation from the family and support from health workers in the form of counseling. ${ }^{8,9}$

The results of cross-tabulation between the level of education and the utilization of the $\mathrm{MCH}$ handbook by pregnant women showed that the categories that were not effective in utilizing the $\mathrm{MCH}$ handbook were mostly found in pregnant women with a low education level of 29 respondents (85.3\%). This is in accordance with the research in 2016, which states that the level of education influences changes in attitudes and behaviour. The low level of education makes it difficult for a person to absorb information and apply it in daily life, especially in terms of health. ${ }^{10,11}$ The less education level of pregnant women, the less the level of awareness of responsibility for health.Based on this, the lower the level of education of pregnant women, the more pregnant women are not effective in utilizing the $\mathrm{MCH}$ handbook.

Based on the results of statistical tests with the Fisher test at Table 2, it was found that there was a significant relationship between the level of education of pregnant women and the utilization of $\mathrm{MCH}$ handbook ( $p$-value $=0.005<0.05$ ) .

This study found that most pregnant women with a low level of education and ineffective use the $\mathrm{MCH}$ handbook. Based on Nursalam's theory, education determines how to receive one's information. Someone with a low education level will hinder the development of one's attitude towards the acceptance of information and newly introduced values. ${ }^{10}$ The less education level of pregnant women, the less informed in the $\mathrm{MCH}$ handbook that pregnant women can receive, the less the behaviour of pregnant women in carrying out information in the $\mathrm{MCH}$ handbook, in this case, the use of the $\mathrm{MCH}$ handbook becomes ineffective. Based on Table 2, it can be seen that the value of Odds Ratio $=7.457$, which means pregnant women with a low level of education have a risk of 7 times ineffective in utilizing $\mathrm{MCH}$ handbook than pregnant women with higher education levels.

The results of cross-tabulation between occupations and utilization of $\mathrm{MCH}$ handbook by pregnant women showed that the categories that were ineffective in using the $\mathrm{MCH}$ handbook were 31 respondents (86.1\%). Contrary to the results research in 2016 at the Kelasan Sleman Public Health Center stating that most pregnant women who use $\mathrm{MCH}$ handbook are pregnant women who do not work because there is more time to pay attention to their pregnancy and get information about maternal and child health through health workers. ${ }^{12,13}$

Based on the results of statistical tests with the Fisher test at Table 2, it was found that there was a significant relationship between the occupation of pregnant women and the use of $\mathrm{MCH}$ handbook ( $p$-value $=0.001<0.05$ ).

This study found that most pregnant women as housewives in the category non-working effectively in utilizing $\mathrm{MCH}$ handbook because according to research in 2017 the status of a housewife cannot guarantee that pregnant women have a lot of free time to read KIA books at home. Pregnant women as housewives have quite a busy schedule taking care of their home needs, their husbands and children. Based on Table 3, the value of Odds Ratio $=11.160$ means that pregnant women with non-working categories have 11 times the risk of being ineffective in utilizing $\mathrm{MCH}$ handbook compared with pregnant women who work.

In 2015 respondents who worked outside and had many friends were very likely to have good knowledge and be more effective in utilizing $\mathrm{MCH}$ handbook compared to respondents who only worked around the house or even those who did not work. Respondents who do not work and are only at home, they get little information as a result of less association with others. The status of pregnant women who work does not guarantee that pregnant women do not have time to read 
the $\mathrm{MCH}$ handbook. ${ }^{10,14,15}$ Pregnant women who receive sufficient information, support, and motivation from the work environment can be more effective in utilizing the $\mathrm{MCH}$ handbooks.

The use of the $\mathrm{MCH}$ handbook is more effective for working mothers, but in 2015 it is recommended for pregnant women to reduce the workload that is too heavy because it will have an adverse impact on their pregnancy. ${ }^{16,17}$

\section{CONCLUSION}

We found that most of the education levels of pregnant women in the low education category were 34 people (68\%) and 36 pregnant women did not work (72\%) Most of the use of the $\mathrm{MCH}$ handbook by pregnant women was 36 people (72\%) were not effective in utilizing it. There is a meaningful relationship between the level of education and occupation of pregnant women and the utilization of the $\mathrm{MCH}$ handbook. This research is expected to be able to inform health care workers and local governments in the upcoming counseling regarding the importance of the $\mathrm{MCH}$ handbook as an effort to reduce maternal and infant mortality, especially in pregnant women with low education and not working.

\section{REFERENCES}

1. Badan Pusat Statistik. Survei kesehatan demografi Indonesia tahun 2015. Jakarta: BPS; 2016.

2. Dinas Kesehatan Provinsi Kalimantan Selatan. Profil kesehatan Provinsi Kalimantan tahun 2016. Banjarmasin. 2017.

3. Dinas Kesehatan Kota Banjarmasin. Profil kesehatan Kota Banjarmasin tahun 2016. Banjarmasin. 2017.

4. Rahayu YP, Mahpolah, Panjaitan FM. Hubungan pengetahuan dan sikap ibu hamil tentang tanda bahaya kehamilan terhadap pemanfaatan buku KIA di UPT. Puskesmas Martapura. Dinamika Kes J Keb Kep. 2015; 6(1): 146-51.
5. Mansur $\mathrm{H}$, Sumiatun. Kepemilikan buku KIA dan keteraturan antenal care. J Pend Kes. 2015; 4(1): 40-5.

6. Sistiarani C, Gamelia E, Sari DUP. Fungsi pemanfaatan buku KIA terhadap pengetahuan kesehatan ibu dan anak pada ibu. J Kes Mas Nas. 2014; 8(8): 353-8.

7. Pandori J, Kartasurya MI, Winarni S. Penggunaan buku KIA sebagai media edukasi pada ibu hamil (studi di wilayah kerja Puskesmas Tlogosari Kulon, tahun 2018). J Kes Mas (e-journal) FKM UNDIP. 2018; 6(2): 63-73.

8. Oktarina, Mugeni. Hubungan pengetahuan, sikap, kepatuhan ibu hamil dan ibu bayi dalam penggunaan buku KIA di Puskesmas Geger dan Kedundung Kabupaten Bangkalan, Jawa Timur, tahun 2013. Buletin Penelitian Kesehatan. 2015; 18(2): 141-50.

9. Green LW, Kreuter MW . Health program planning: an educational and ecological approach. Ed 4 . NY: McGraw-Hill Higher Education. 2005 4(1): 126-31.

10. Setyaningrum SS, Wuryanto MA, Astuti LD. Gambaran tingkat pengetahuan, sikap dan praktik ibu hamil terhadap penggunaan buku KIA sebagai sumber referensi di Leyangan Ungaran. J Keb Panti Wilasa. 2015; 6(1): 1-8.

11. Bhuiyan SU, Begum HA, Lee AS, Shao YW. Maternal and Child Health Handbook: Utilization and lessons learned from selected evidence-based studies. J Public Health Develop. 2017; 5(2): 88-100.

12. Notoadmodjo S. Promosi Kesehatan dan Ilmu Perilaku. Jakarta: Rineka Cipta; 2012. 4(1): 120-30.

13. Mohdari, Sinambella DP, Saropah M. Hubungan umur dan pendidikan ibu primigravida dengan kepatuhan kunjungan ANC. Dinamika Kes J Keb Keperawatan. 2014; 5(2): 39-45.

14. Ruslinawati, Sukarlan, Hanan. Perbedaan status pekerjaan ibu hamil dengan frekuensi kunjungan antenatal care (ANC) di wilayah kerja Puskesmas Pekauman Kota Banjarmasin tahun 2016. J Kep Suaka Insan. 2016; 1(2): 1-9.

15. Destria D. Faktor-faktor yang berhubungan dengan tingkat pemahaman ibu hamil terhadap pesan antenatal care yang terdapat di dalam buku KIA [Karya Tulis Ilmiah]. Semarang: Universitas Diponegoro; 2010.

16. Ainiyah $\mathrm{NH}$. Hubungan pemanfaatan buku kesehatan ibu dan anak (KIA) dengan tingkat pengetahuan dan perilaku kesehatan ibu hamil trimester III di Puskesmas Jagir Surabaya [disertasi]. Yogyakarta: Universitas 'Aisyiah; 2017.

17. Depkes RI. Petunjuk teknis penggunaan buku kesehatan ibu dan anak (KIA). Jakarta: Depkes dan JICA; 2015. 